\title{
THE CONTRIBUTIONS OF AGRICULTURAL GROWTH TO POVERTY REDUCTION IN ETHIOPIA ${ }^{1}$
}

\author{
Getahun Tafesse ${ }^{2}$
}

\begin{abstract}
${ }^{3}$
This study investigates agricultural growth-poverty relationships at the national and household levels. A rural household model is used to measure the impact of agricultural growth (or decline) on consumption first and the effect of consumption changes on poverty using regression analyses. Two approaches are used here to estimate the agricultural growth elasticity of poverty. First, the growth elasticity of poverty is determined and then using the agriculture elasticity of growth, the agriculture growth requirement for the change in poverty is estimated indirectly. In the second approach, a two-stage analysis is used to arrive at the growth requirement by estimating first the determinants of welfare (household consumption expenditure) and estimating the poverty impact of a certain growth using the relationship between expenditure and poverty incidence.
\end{abstract}

\begin{abstract}
Accordingly, a forty-year time-series national account data has indicated that a 1 percent growth in agriculture would lead to a 0.32 percent growth in GDP. Given the GDP growth elasticity of poverty, it also followed that a 1 percent increase in agricultural production would lead to a 0.24 percent decline in poverty incidence at the national level. At the Household level, the base simulation has provided a poverty incidence of 40.2 percent in rural areas with 11.2 and 24.9 poverty gap and severity respectively for the year 1995/96. Given the actual and base simulation poverty measures and assuming the percentage change in percapita value added of agricultural production reflects the same percentage change in consumption per capita (adult) and that income distribution remains the same, the application of the same poverty line in real terms ${ }^{4}$, has provided a poverty incidence of 63.6 percent and a poverty gap of .22 for the year 2000/01. Such a rapid increase in poverty level goes very well with the general perception of the public as expressed during the PRSP consultation and with other studies by non-governmental organizations. Here agricultural growth elasticity of poverty becomes -3.62 , which is very high. When inflation is ignored the agricultural growth elasticity of poverty becomes -2.12. Based on another assumption that takes the long-term trend in agricultural growth, poverty incidence and gap for 2000/01 become 46.5 percent 13.7, implying agricultural growth poverty elasticity of 0.98 , or almost equal percentage change in opposite direction. So, it is likely that a one percentage increase in agricultural per capita value added will result into a one percent decline in poverty level of rural households.
\end{abstract}

\footnotetext{
${ }^{1}$ The final version of this article was submitted in December 2006.

${ }^{2}$ Formerly Senior Researcher at EEA/EEPRI, Currently M\&E Advisor, Ethiopia Canada Cooperation Office.

${ }^{3}$ It is acknowledged that this work has substantially benefited from suggestion and comments provided by Dr. Alemayehu Seyoum and Dr, Assefa Admassie, who have reviewed the document and provided valuable comments. Ato Fantu Guta has also contributed by reviewing and commenting on the technical estimation formulas and procedures used in the study.

${ }^{4}$ Note that, annual inflation based on CPI has been on average 2.64 during the five year period, which means the poverty line has to be increased by 13.9 percent. The poverty line in 2000 becomes, therefore, 1224 birr.
} 


\section{Introduction}

Ethiopia is basically a rural society with only a small percentage (15 percent) of the population living in the capital city, secondary cities and small urban towns in different regions of the country. Moreover, the outskirts of so-called urban centers and their surrounding areas are commonly rural. The livelihood of the population in rural areas is mainly based on agriculture - typically mixed farming.

In terms of economic development, Ethiopia is one of the least developed and therefore the poorest country in the world. A recent World Bank rankings of GNP per capita put Ethiopia $206^{\text {th }}$ and last, with income per head of only US $\$ 100$ in 1999, compared to the sub-Saharan Africa (SSA) average of US $\$ 500$ (World Bank, 2000). Poverty in Ethiopia is, therefore, widespread and deep-rooted and constitutes the priority development challenge in the country. Currently it is estimated that close to half of the population is under the national poverty line. Based on exercise undertaken in this study, about 90 percent of the population would fall under poverty line if the international poverty line of a dollar a day per person is used. It is also clearly shown that the incidence and severity of poverty is higher in rural areas.

Agriculture constitutes the principal source of income and employment for the majority of the population. Greater proportion of the foreign exchange the country earns also comes from this sector. The sector accounted about $68.6 \%$ of GDP during the Imperial period and about 56\% during the last regime. The dominance of the sector has continued during the last decade and currently it stands at $43 \%$ (Table 2.1 ). It is also the leading sector in terms of providing employment in the country. According to the 1984 and 1994 population and housing censuses, about 89 percent of the population was engaged in agricultural activities.

Agriculture in Ethiopia is typically characterized by small holder and subsistence farming which is highly dependent on rainfall. The urban livelihood is also highly dependent on the rural economy and as such small farm constitutes the life support mechanism of the country. Understanding poverty in the country necessitates therefore knowledge about farm economy in the country. Although small scale subsistence farming is the dominant feature there are, however, great diversities and characteristics of different farm systems that operate under this domain. It is possible to categorize the different systems, however, into different sub groups such as Cereal growing, Enset, Pastoral, Subsistence and Cash Crop producing farm systems.

Efforts to estimate the consequences of agricultural policies are often confounded by complex behavioral patters and characteristics of households in semi- 
commercialized, rural economies (Singh, et al.). Most agricultural households in Ethiopia, for example, mainly produce for own consumption but also for sale, which can have many purposes - saving, procuring food or non-food items and tax or loan repayment. These households purchase some of their inputs (ex., fertilizer) and provide some (such as family labor) from their own resources. Any change in the policies governing agricultural activities will therefore affect not only production, but also consumption and labor supply.

Poverty in Ethiopia cannot also be analyzed without looking at the larger context of the rural nature of the country, drought disaster, environmental degradation, rapid population growth and general structural features of the economy. The country faces chronic food deficit as a result of which about 5 million people annually depend on food aid.

The broad outline of the government strategy for reducing poverty in Ethiopia as described in the PRSP document comprises the following elements: An AgricultureDevelopment Led Industrialization (ADLI), continuing implementing economic reform programs, civil service and judicial reforms, decentralization and capacity building. The - Agriculture Development Led Industrialization - strategy (ADLI) comprises the umbrella development strategy for the country. Ethiopia provides an interesting case study considering the ADLI strategy, small-scale agriculture based economy and the recent agricultural products price slumping and the associated factors and aftereffects.

This strategy revolves around making the small-agricultural farmer the engine of growth. It is argued that what the average farmer needs to kick start the growth process is access to combined provision of land, skill, and capital (GOE, IPRSP, 2000). The smallholder farming family is made, therefore, the focus of economic development with a massive agricultural extension (focused on provision of improved seeds and fertilizer) and credit scheme, and expansion of primary education, primary health care, rural water supply and rural roads.

In Ethiopia land is also under state ownership and neither farmers can sell their plot of land nor private investors can purchase land from rural dwellers. With these policy and institutional background, the trends and dynamics of agricultural growth and poverty reduction in Ethiopia are interesting to investigate.

In this study attempt is made to explore the role and externalities of improvement in agricultural production for poverty reduction in the country. The study attempts to specify and measure the different channels under which agricultural growth impacts on poverty. The channels can be broadly divided as those operating through the 
market mechanism and those that are not. At the macro level, the degree of relationship between the performance of the agriculture sector and the overall economy is explored using long-term time-series data. Here, the relative contribution of agriculture as compared to other sectors is also investigated. First, the GDP growth elasticity of poverty is determined and consequently the agricultural growth elasticity of poverty is calculated using agricultural growth elasticity of GDP determined earlier. In this way, the contribution of the agriculture sector to poverty reduction at the national level is estimated indirectly. In addition, the direct agricultural elasticity of poverty reduction is determined using two stage approaches, which sequentially linked determinants of income to household expenditure level and using the Foster, Greer and Thorbeck P- $\alpha$ measures, household expenditure levels are linked to poverty measures.

The identification of the main channels through which agricultural growth impacts poverty is highly dependent on the system of agriculture being considered. That is why a broad characterization of the agriculture system is made in the study before identification of possible channels through which agricultural growth impacts poverty. In Ethiopia, agriculture is mainly subsistence farming with huge unemployment and underemployment and operates under a system of public ownership of land. The channels identified in the study are based therefore with this framework in mind.

Moreover, to capture fully the roles and externalities of agricultural growth in poverty reduction, an understanding of the microeconomic behavior of agricultural households is necessary. It is essential to know the determinants of poverty, what factors determine the level of farm production and households consumption and the supply of labor. The agricultural household model is applied here given the advantage models capture both the production and consumption behavior of farm households. The model assumes that households are price-takers and is therefore recursive. Wellbeing is defined in terms of households' consumption expenditure level. Nutritional intake level is also used as an alternative measure of living standard of households. How resources are allocated within a household also determine the level of impact on poverty arising from increase in household income. Intra-household distribution of income is not, however, the subject of this study.

The paper is outlined into eight major sections, which are consequently arranged to provide first background and characteristics of the agricultural system in Ethiopia, discuss the various channels through which poverty is affected, provide estimation of these channels and finally identify key conditions that affect size of impact of agricultural growth and based on which conclusions and policy recommendations are provided. 


\section{The macro economy and the agriculture sector 2.1 Long-term relationships}

Agriculture is the basis of the national economy. It continues to be the dominant sector in spite of the fact that the contribution of the sector in the GDP has been continuously declining over the past four decades. The share of agriculture in GDP on average was $69 \%, 56 \%$ and $49 \%$ during the Imperial, Derge and EPRDF periods respectively (Table 2.1 ).

Table 2.1: The past forty year relationship between agriculture and GDP

\begin{tabular}{lcccccc}
\hline & $\begin{array}{c}\text { GDP } \\
\text { (In mil.) }\end{array}$ & $\begin{array}{c}\text { Agri. } \\
\text { (In mil.) }\end{array}$ & $\begin{array}{c}\text { Share of } \\
\text { Agri. (\%) }\end{array}$ & $\begin{array}{c}\text { Population } \\
\text { (In mil.) }\end{array}$ & $\begin{array}{c}\text { GDP } \\
\text { percapita }\end{array}$ & $\begin{array}{c}\text { Agri. } \\
\text { percapita }\end{array}$ \\
\hline Imperial (1962-73) & 6560.7 & 4463.5 & 68.6 & 27.3 & 238.9 & 194.9 \\
Derg (1974-1990) & 9515.5 & 5289.2 & 55.9 & 39.3 & 242.9 & 160.6 \\
EPRDF (1991-2002) & $14,214.7$ & 6837.6 & 48.7 & 58.5 & 241.6 & 136.9 \\
\hline
\end{tabular}

Source: Own computations based on national account data

Overall the agriculture sector grew annually by 1.89 percent on average during the last forty years $(1962-2002)$ (Table 2.2). The sector grew annually on average by 2.1, 1.5 and 2.2 percent during the Imperial, Derge and EPRDF periods respectively. As a result the percapita agricultural value added has actually declined by 0.9 percent (Table 2.3).

Table 2.2: Forty year summary of economic performance

\begin{tabular}{lcccc}
\hline & Imperial & Derg & EPRDF & Overall \\
\hline Agriculture & 2.14 & 1.53 & 2.21 & 1.89 \\
Industry & 7.53 & 1.35 & 6.19 & 4.46 \\
Distributive Services $^{5}$ & 8.27 & 1.26 & 6.84 & 4.81 \\
Other Services & 7.29 & 4.97 & 7.39 & 6.30 \\
GDP & 3.80 & 1.89 & 4.50 & 3.15 \\
\hline
\end{tabular}

Source: Own computations based on national account data

The performance of the remaining sectors in relative terms was much better than the agriculture sector. Industry, distributive services and other services on average grew by $4.46,4.81$ and 6.3 percent annually during the last four decades. Although at very low levels, these sectors have also registered positive growth in terms of per capita value added. GDP percapita in general grew only by average 0.58 percent annually during this long period, showing poor performance of the economy over an extended period.

\footnotetext{
${ }^{5}$ Distributive services include transport and communication related activities while "other services" include general administration and defense.
} 
Table 2.3: Forty year summary of economic performance - in percapita terms

\begin{tabular}{lcccc}
\hline & Imperial & Derg & EPRDF & Overall \\
\hline GDP percapita & 1.49 & -0.67 & 1.57 & 0.58 \\
Agriculture percapita & -0.04 & -1.25 & -1.36 & -0.93 \\
Indus. percapita & 4.4 & -2.1 & 1.56 & 0.80 \\
\hline
\end{tabular}

Source: Own computations based on national account data

It can be concluded from Table 2.4 that the poor performance of the overall economy is mainly due to the poor performance of the agriculture sector. Similar pattern of growth rates under the different regimes is observable between GDP and the agriculture sector. Coupled with relatively higher population growth rates, the sector registered negative percapita growth rates under all the past three regimes.

Table 2.4: Forty year relationship between agriculture and GDP - growth rates

\begin{tabular}{lccccc}
\hline & GDP & Agriculture & Population & GDP percapita & Agri. percapita \\
\hline Imperial & 3.80 & 2.14 & 2.3 & 1.49 & -0.04 \\
Derg & 1.89 & 1.53 & 2.6 & -0.67 & -1.25 \\
EPRDF & 4.50 & 2.21 & 2.9 & 1.57 & -1.36 \\
\hline
\end{tabular}

Source: Own computations based on national account data

The share of the various sectors in GDP over different periods in the past is shown in Table 2.5. The decline in share of agriculture in the overall economy does not show, however, structural transformation that usually happens when industrialization occurs. The share of industry has actually declined during the past decade as similar decline was observed in the agriculture sector. These declines were compensated by a rapid increase in other services sector, which is dominated by public administration and defense. So, the long-term trend of the performance of the economy does not seem to be healthy.

Table 2.5: Sectoral percentage shares in GDP

\begin{tabular}{lccc}
\hline & Imperial & Derge & EPRDF \\
\hline Agriculture & 68.6 & 55.9 & 48.7 \\
Industry & 9.1 & 11.4 & 10.6 \\
Distributive Services & 11.4 & 14.3 & 14.1 \\
Other Services & 10.9 & 18.4 & 26.6 \\
& 100.0 & 100.0 & 100.0 \\
\hline
\end{tabular}

Source: Own computations based on national account data 


\subsection{Contribution to GDP}

Another look at the relative importance of the various sectors in the economy is provided through their relative contribution to GDP growth. As is shown in Table 2.6, the contribution of agriculture to overall GDP growth has declined from about 39 percent during the Imperial period to about 22 percent under the current government. Whereas, the contribution of other services has increased from 21 percent to 44 percent during the same period. Hence, in terms of importance to growth performance, other services contribute more than the contribution by the agriculture sector.

Table 2.6: Contribution to GDP growth (in \%)

\begin{tabular}{lccc}
\hline & Imperial & Derge & EPRDF \\
\hline Agriculture & 38.9 & 38.5 & 22.2 \\
Industry & 17.0 & 6.5 & 13.6 \\
Distributive Services & 23.5 & 4.9 & 20.5 \\
Other Ser & 20.6 & 50.2 & 43.8 \\
& 100.0 & 100.0 & 100.0 \\
\hline
\end{tabular}

Source: Own computations based on national account data

Trends in average annual growth rates of percapita value added of the different sectors indicate that GDP percapita value added is highly correlated with agricultural value added than other sectors. Analysis of 50 year national account data has clearly indicated, therefore, the close relationship between the overall performance of the economy and the performance of the agricultural sector.

A simple regression ${ }^{6}$ analysis was made to quantify the linkage between agricultural and GDP growth rates in terms of elasticities. The results are summarized in Table 2.7. According to the estimation result, a 1 percent growth in agriculture would lead to a 0.32 percent growth in GDP. The fact that other sectoral elasticities of growth with respect to GDP are lower than this indicates that agriculture is the predominant sector in determining income at the national level.

Growth in agricultural value added is, therefore, the most determining factor of real GDP percapita growth in Ethiopia. Although "other services" has the highest elasticity, the proportion of its contribution to GDP growth is much smaller than agriculture. As s result, during the two regimes, for example, inspite of positive real percapita growth

\footnotetext{
${ }^{6}$ Growth in GDP is modeled as a function of growth in agriculture, industry, distributive and other services.
} 
rates in the non-agricultural sectors, GDP percapita registered a negative growth in line with the growth in agriculture percapita.

Table 2.7: Sectoral elasticities of GDP growth

\begin{tabular}{lccc}
\hline & B & Avg & E \\
\hline Agriculture & .525 & 1.89 & 0.32 \\
Industry & & 4.46 & \\
Distributive Services & .125 & 4.81 & 0.19 \\
Other Services & .229 & 6.3 & 0.46 \\
\hline
\end{tabular}

Source: Own computations based on national account data

\section{Agricultural growth channels that affect poverty}

The identification of the main channels through which agricultural growth impacts poverty is highly dependent on the system of agriculture being considered. For a person who has in mind a highly privatized and large-scale commercialized agriculture, the benefits of growth are mainly conceived from the recipients' end. In this perspective, wage differentials and movement of labour among different sectors and between rural and urban areas also get precedence as the most direct transmission mechanisms. The picture one envisages under small-scale, subsistence and public land holding system could be substantially different, however.

In Ethiopia, agriculture is mainly subsistence farming with huge unemployment and underemployment and operates under a system of public ownership of land. The channels identified in this study are based therefore with this framework in mind. In other words, the most direct benefit of agricultural growth is improvement in welfare of the small-holder assuming price will not decline due to shortage of effective demand. The labour market consequence is primarily envisaged in terms of more labor absorption within the rural areas with little impact on rural wage rate in the short term. Since the agriculture sector is unlikely to attract labour from other sectors and urban areas under such a system, the general equilibrium effect through the increase of unskilled labour wage rate in urban areas need not be automatic.

The effect of higher agriculture output leading to lower food prices should also be seen from two angels: the producers and consumers. In the case of Ethiopia, given that the producers are mainly small farmers, a reduction in food prices could increase poverty among the rural poor rather than decrease it. As the recent experience of agricultural produces' prices slumping has indicated, an increase in smallholders' income need not necessarily follow an agricultural growth. The urban poor is likely to 
benefit from a reduction in food prices mainly through higher real wage rate the effect of which could be dampened however by traders and brokers profit margins.

The benefits to the urban poor could also come through expanding economic activity comprising mainly increased volume of trade but also from processing activities which augment the demand for labour (both in formal and informal self-employment endeavors). The positive effect of agricultural growth on employment also occurs in rural areas. In Ethiopia, seasonal labour demand associated with harvesting periods for coffee, teff and other grains is common. Hence, an increase in agricultural productivity is likely to increase the demand for labour thereby benefiting rural unskilled laborers.

The poverty reducing impact of agricultural growth through its effects on non-farm production and consumption activities is an interesting area to investigate. The following points are considered in examining this channel:

- Agro-processing industries in Ethiopia are at their embryo and infancy stages dampening the potential impact on poverty reduction of an agricultural growth.

- Lack of infrastructure and isolation of rural communities from the rest of the country and markets.

- The potential release of extra labour from households augmenting the opportunity to engage in non-farm activities.

- The immediate possible effect of increased production and trade in non-food items such as clothing, footwear, etc.

- Increased opportunity for improved utilization of health and education services. And second-round effect of this on enhancing agricultural growth.

Agricultural growth helps to reduce poverty in at least seven main channels: First, it provides those households engaged in agricultural activities with increased level of production thereby increasing their access to food. Secondly, higher output could be converted into higher income, assuming price would remain constant, which would then increase households' access to non-food basic requirements. Poor entitlement or purchasing capacity is a key constraint that makes households vulnerable to famine.

In Amhara region of the country, for example, grain production in 1999/2000 was 20\% in excess of consumption needs. Yet 2.8 million people in Amhara (representing 17\% of the region's population) became locked into famine zones and faced risk according to FAO. Whereas Amhara's grain surpluses were in excess of 500,000 tons, its relief food needs have been tagged by international community as close to 300,000 tons. 
Thirdly, growth in agricultural produce is likely to reduce the cost of food for nonagricultural poor communities both in rural and urban areas (through increase in real wages). Fourthly, it provides with an increased opportunity for poor people to be engaged in productive and trade activities and earn income, i.e., as producers of petty items, labourers, brokers, traders of food items and suppliers of basic non-food commodities. It is known, for example, that a decline in the performance of the agriculture sector results into urban wages collapse and drives unemployed seasonal farm workers and the landless peasants into abysmal poverty. Fifthly, it can lead to increased employment opportunities in rural areas, although the potential of this in Ethiopia is limited because of small holder farming dominance.

Sixthly, it leads to increased government income through taxation and possibly increased foreign exchange earning through export. The financial resources generated out of growth taxation can be used to finance government pro-poor services. Finally, it creates spillover effects on social capital and other sectors of the economy. Some of the market failures and other external factors that could prevent the effective contribution of agricultural growth to poverty reduction include:

a) The rural-sector in Ethiopia is largely non-monitized. Rural communities livelihood, on relative terms, is less dependent on the market system. As a result, an increase in level of agricultural production may not effectively translate into an increase in rural households income. (It is likely that an increase more than the normal average production level could simply be stored with reduced motive for production in the next season).

b) Besides absence of market, sporadic tiny open-field markets characterize rural settings. The goods available in these markets are limited constraining the choice farm households have for consumption. For example, iodized salt may simply be inexistent leading to Vitamin A deficiency and consequently to blindness - a major feature of poverty in Ethiopia.

c) Institutions and regulations governing a market system are more or less absent in rural areas. The availability of banks and associated functions (saving, credit, checking account, etc.), salary/wage employment, trade/investment/finance bureaus (licensing, tax, ) is limited.

d) The impact farm improvement has on the expansion of non-farm activities is likely to be limited. Subsistence life style and farming together with poor knowledge and other constraining variables desired and normally expected clothing, footwear, food processing, etc. may not mushroom as expected following agricultural boom.

e) Rural communities are usually isolated societies who have weak linkage with the rest of the country due to absence of infrastructure such as roads, communication and transport - i.e., barriers to connection with outside markets. Limited opportunities, poor access to commodities, less pressure from 
competition, etc. work against incentives and motivation for sustaining agricultural growth and continuous improvement in welfare situation.

f) Lack of effective and sufficient urban food demand also undermines the poverty reducing outcomes of agricultural growth in rural areas. This was remarkably witnessed in recent period in Ethiopia where agricultural products prices slumped down following an increase in agricultural production which were not however matched by commensurate increase in food demand.

g) The impact of agricultural growth on urban poverty is undermined by monopoly of agricultural traders and brokers, undue tariffs and taxes, etc. which make significant differences between farm-gate prices and retail prices. The poor in urban areas also cannot afford to purchase agricultural produce in bulk, which exposes them to further loses. However, the urban poor is destined to benefit from lower food prices.

h) Finally, the pattern of growth whether it is broad based or not and initial inequality conditions matter in determining the impact of growth on poverty.

\section{The roles of agriculture to rural farm societies}

First and foremost, the benefits of agricultural growth directly accrue to rural farm households. As was discussed earlier, agricultural households are the main form of economic organization in Ethiopia. Most can be described as subsistence farmers given that they produce mainly for consumption. Hence, they are characterized both as consumers and producers. Even these farmers, however, are likely to purchase some of their food items (such as salt, oil, kerosene, etc.) from the market. They are categorized therefore as semi commercial with those households who partially produce with the intention of selling at the market.

An agricultural household model is a model that provides a framework for analyzing household behaviors integrating consumption, production and labor (and therefore leisure) decisions. Here a unitary and recursive household model is used because it fits well into the familiar consumer choice framework. Moreover, the collective household mode could not be applied because of lack of detailed data on the distribution of resources among members of household. The available data is at household level.

\subsection{Agricultural growth elasticity of poverty}

Two approaches are used here to estimate the agricultural growth elasticity of poverty. First, the growth elasticity of poverty is determined and then using the agriculture elasticity of growth, the growth rate in agriculture is estimated indirectly. 
In the second approach, a two-stage analysis is used to arrive at the growth requirement by estimating first the determinants of welfare (household consumption expenditure) and estimating the poverty impact of a certain growth using the relationship between expenditure and poverty incidence.

Note that there is a general agreement that growth is an important and necessary factor for poverty reduction. Growth by itself however is not sufficient unless it is broad-based and allows the poor or low-income group to participate in the process. It should be noted that the degree of poverty depends upon the average level of income and the extent of inequality in income distribution (see, for example, Kakwani, 1993). Hence, agricultural growth affects poverty in so far as it affects average level of income and inequality. Hence, in this analysis inequality is assumed to remain the same.

\section{National income elasticity of poverty}

Poverty incidence depends on real per capita (per adult) income (expenditure), poverty line and income inequality. Hence, it is possible to start with a generalized form of poverty function (Ali, 1998, ECA 1999) as given in equation below:

$$
\mathrm{Po}=\mathrm{P}(\mu, z, \mathrm{~m})
$$

Where, Po is index of poverty, $\mu$ is mean per capita income, $z$ is the poverty line, $m$ is measure of income inequality.

Total differentiation of the poverty function provides the following formula:

$$
\partial \mathrm{P}=\frac{\partial P}{\partial \mu} d \mu+\frac{\partial P}{\partial z} d z+\frac{\partial P}{\partial m}+\frac{\partial P}{\partial m} d m
$$

Since $\mathrm{P}$ is homogeneous of degree zero with respect to $\mu$ and $z$, by Euler's theorem, we will have:

$$
\begin{aligned}
& \frac{\partial P}{\partial z} d z+\frac{\partial P}{d \mu} d \mu=0 \\
& d z=-\frac{\partial z}{\partial \mu} d \mu \quad \text { given that } \frac{d z}{d \mu}=\frac{\partial z}{\partial \mu}
\end{aligned}
$$

Hence, 


$$
\partial P=\frac{\partial P}{\partial \mu} d \mu-\frac{\partial P}{\partial \mu} \frac{\mu}{Z} d z+\frac{\partial P}{\partial m} d m
$$

Growth rate in $\mathrm{P}$ is given by:

$$
\begin{aligned}
& \frac{d P}{P}=\frac{\partial P}{\partial \mu} \frac{\mu}{P} \frac{d \mu}{\mu}-\frac{\partial P}{\partial \mu} \frac{\mu}{P} \frac{d \mu}{d z} \frac{Z}{\mu} \frac{d z}{Z}+\frac{\partial P}{\partial m} \frac{m}{P} \frac{d m}{m} \\
& =\frac{\partial P}{\partial \mu} \frac{\mu}{P} \frac{d \mu}{\mu}-\frac{\partial P}{\partial \mu} \frac{\mu}{P} \frac{\partial z}{\partial \mu} \frac{\mu}{Z} \frac{\partial \mu}{\partial z} \frac{Z}{\mu} d \mu+\frac{\partial P}{\partial m} \frac{m}{P} \frac{d m}{m} \\
& =\eta \frac{d \mu}{\mu}-\eta(\varepsilon)(\delta) d \mu+v \frac{d m}{m} \\
& \eta \quad=\frac{\partial \quad P}{\partial \quad \mu} \frac{\mu}{P} \quad \text { and } \delta=\frac{\partial \mu}{\partial z} \frac{Z}{\mu} \\
& \varepsilon=\frac{\partial \quad z}{\partial \mu} \frac{\mu}{z}
\end{aligned}
$$

where

Using a related formula with above and based on parameters derived from an econometric equation fitted by Ali (1998), the growth elasticity of poverty in Ethiopia is estimated to be 0.76 (Befekadu, et al (2002). The formula used by Befekadu, et al is slightly different from the above, which is partially derived here.

Given the earlier estimate that the agricultural elasticity of GDP growth is 0.32 , it follows that a 1 percent increase in agricultural production would lead to 0.24 percent $\left(.32^{*} .76\right)$ decline in poverty incidence. Although this seems to be on the low side, it should be noted that the reduction in poverty is at national level, which indicates that the elasticity of poverty to agricultural growth would be higher if only rural poverty is considered. If for the moment we assume, poverty line and income inequality remain the same, then poverty incidence will be determined by the growth in per capita income. 
In Ethiopia, currently, there are, however, only two data points that provide poverty incidence and percapita levels at the same time - 1995/96 and 1999/00. Taking average growth rates for the past five years before the respective data points indicate that on average per capita income has declined, whereas the available poverty estimates show a decline in poverty. This will give a positive elasticity, which is unlikely to be true. Hence, it is assumed that poverty incidence in the given years is affected by percapita income levels in the previous years, which provided a growth elasticity of poverty -0.25 .

\section{Household expenditure elasticity of poverty}

The second approach initially considered a three-stage analysis, which for lack of time and data, however, settled for a two-stage analysis by integrating the first model into the second one.

$1^{\text {st }}$ stage: Determining Income: Household's income as a function of yield, labour input and land and determining consumption expenditure (demand) as a function of income, prices and saving and other household welfare determining variables such as household size, asset base and access to infrastructures.

$2^{\text {nd }}$ stage: Determining the expenditure elasticity of poverty incidence

Poverty is a function of expenditure, poverty line and income inequality. At the household level, it is possible therefore to estimate the expenditure elasticity of poverty by regressing poverty on expenditure, assuming constant poverty line in real terms and that income distribution remains the same. The models are developed in subsequent sections.

\subsection{Different scenario analyses and simulation estimates}

As was mentioned earlier, we have two points in time concerning actual trend in poverty situation in the country: 1995/96 and 1999/00. The poverty incidence levels in these two periods are 45.5 and 44.2 respectively. These indicators are used to forecast and simulate different scenarios under conditions of with and without improvement in the performance of the agriculture sector.

\section{Trend analysis}

The trend analysis over four decade period indicates that by 2020 the poverty incidence will be 39 . The implied average declining rate (annual reduction) is $3 \%$. 
This is trend based on five-year period laps. Annual based trend analysis provides similar result as indicated below. Using actual growth rate between the two periods (1995-2000) and extrapolating to 2020 provides a poverty incidence of 39.4. The average annual reduction rate is $2.9 \%$.

The simple forecasting exercise made on poverty incidence demonstrates that Ethiopia needs to undergo fundamental change in productivity levels to meet the millennium goals, if they were to be achievable. Simple forecasting and alternative growth scenarios will be made using the simulation approach below.

\section{Simulation approach}

The purpose here is to illustrate the impact of agricultural growth on poverty using estimated parameters of determinants of per adult ${ }^{7}$ household consumption expenditure and the relationship of this welfare indicator with poverty incidence functions.

$$
\ln \left(C_{j}\right)=\beta^{\prime} X_{j}+\varepsilon_{j}
$$

Using the estimated parameters $(\beta)$ in the consumption model, predictions of consumption per adult for each household $\mathrm{j}$ can be generated as follows:

$$
\hat{C}_{j}=e^{\hat{\beta} X_{j}}
$$

Corresponding to every predicted level of consumption, there is a probability that the household being poor $\left(P_{\theta, j}\right)$, which is given by:

$$
P_{\theta, j}=\int_{0}^{z}\left(\frac{Z-C_{j}}{Z}\right)^{\theta} f\left(C_{j}\right) d C_{j}
$$

Where $f\left(C_{j}\right)$ is the probability function of per capita consumption of household $\mathrm{j}$ and $Z$ is the poverty line.

Under the assumption that the random disturbance term of the consumption model is normally, independently and identically distributed with mean 0 and variance $\sigma^{2}$, the distribution of per capita consumption follows a log normal distribution. Hence, the probability density function of the per capita consumption is given by

\footnotetext{
${ }^{7}$ Adult equivalent is calculated based on adult equivalents scale developed for East Africa and used by the World Bank.
} 


$$
f\left(C_{j}\right)=\frac{1}{C_{j} \sigma \sqrt{2 \pi}} \exp \left\{-\frac{1}{2 \sigma^{2}}\left(\ln \left(C_{j}\right)-\beta^{i} X_{j}\right)\right\}
$$

When $\theta$ takes a value of 0 , the poverty measure boils down to the head-count index, which is given by:

$$
P_{0, j}=\int_{0}^{z} \frac{1}{C_{j} \sigma \sqrt{2 \pi}} \exp \left\{-\frac{1}{2 \sigma^{2}}\left(\ln \left(C_{j}\right)-\beta^{\imath} X_{j}\right)^{2}\right\} d C_{j}=\Phi\left(\frac{\ln (Z)-\beta^{\imath} X_{j}}{\sigma}\right)
$$

The last term provides, therefore, the estimated probability that a household being poor, measured by the head-count index given that $\phi$ is the standard normal distribution function, $\sigma$ is the standard error of the regression, and $\wedge$ indicates estimated values. It is found preferable to compute the probability of being poor associated with any given level of predicted consumption, rather than classifying households as being poor or non-poor depending on the level of predicted consumption relative to the poverty line. The weighted average of the household probabilities of being poor gives the predicted national head-count index ${ }^{8}$.

According to the formula derived earlier, poverty is a function of expenditure, poverty line and income inequality. At the household level, it is possible therefore to estimate the expenditure elasticity of poverty by regressing poverty on expenditure, assuming constant poverty line in real terms and that income distribution remains the same.

The above formulas are applied to a national household income consumption and expenditure survey data set that was collected in 1995/96. The data is nationally representative. Given however our interest is to estimate agricultural growth elasticity of poverty, the data set is disaggregated and only the rural data is used in the estimation exercise. First a brief explanation is given below on the variables used in the estimation and the estimation results will follow.

\section{Deflated per adult total expenditure}

The dependent variable used is the deflated per adult total expenditure at household level. There is a general agreement that household welfare can be approximated by level of its expenditure. Moreover, since this variable is used in estimation of poverty measures, modeling it directly provides the advantage of simulating different scenarios and consequently determining corresponding poverty indicators.

\footnotetext{
${ }^{8}$ The weight variable used here is the population weight.
} 
To arrive at this figure, household size was converted into adult equivalent using adult equivalent scales. On the expenditure side, spatial price index was developed using the Lasperian price index formula and household nominal expenditure figures were converted into real values so that they are comparable across households and areas.

The list of independent variables estimated using the above formulas include the following:

Age of the head of the household

Participatory assessments have indicated that household heads becoming old aged is a factor that affects the well-being of the household. Hence, this variable is included in the model. Given that this is a continuous variable, the natural logarithm of the variable is included in the model as one of the determinants of the welfare of the household.

\section{Education level of the head of the household}

Similarly many studies in the past have established close correlation between the level of education of the household head and the level of its well-being. Given that this is a continuous variable, the natural logarithm of the variable is included in the model as one of the determinants of the welfare of the household.

\section{Household size}

Given that the dependent variable takes into account household size indirectly through adult equivalent, the relevance of this variable is diminished. However, it is included given that it is usually used as a determining variable and for the sake of completeness.

\section{A dummy variable for engagement in non-farm activities}

This variable is constructed by looking into the actual data sets and differentiating those households that are engaged in non-farm activities, both as a full-time occupation and as supplementary activity, as opposed to those who are purely engaged in farm activities. In this way, some idea could be derived on the importance of non-farm activity in determining consumption.

\section{Owning farm animals}

The most important point here is whether farm households have oxen. Since, however, the question in the survey was framed in more general terms, the variable is incorporated as potential determinant of welfare as it is.

\section{Owning transport animals}

Given the scattered nature of settlement in rural areas and difficulty of access to market, ownership of transport animals is likely to make significant difference in the wellbeing of rural households. Hence, it is included in the estimation exercise. 


\section{Land ownership}

This is a key variable that plays critical role in the welfare of rural people. Ownership also indicates tenure security and, therefore, long-term investment in agriculture.

\section{Distance to various infrastructure}

The variables included under this category include distance from Market, Primary School, Health Center and Transport facilities. Whereas these variables are important in themselves in determining welfare, access to such infrastructure also indicates degree of integration with the rest of society, which has likely positive impact on welfare.

\section{Asset ownership}

This is a broad category under which many variables are included in the regression analysis. Key variables selected and incorporated in the model include: ownership of farm tools, radio, and a house.

The following represents the results generated:

\begin{tabular}{|c|c|c|c|c|c|c|}
\hline & & & $\mathbf{T}$ & $P>|t|$ & \multicolumn{2}{|c|}{ [95\% Conf. Intery } \\
\hline & & .0548979 & -0.34 & & & \\
\hline LeducHead | & .0779454 & .0217056 & 3.59 & 0.000 & .0353605 & . 1205303 \\
\hline HHsize | & -.0874874 & .0071496 & -12.24 & 0.000 & -.1015144 & -.0734605 \\
\hline NonfarmD | & -.0886524 & .0285051 & -3.11 & 0.002 & -.1445775 & -.0327273 \\
\hline OwnFanim | & .0611495 & .0410369 & 1.49 & 0.136 & -.0193621 & 141661 \\
\hline OwnTranA | & -.1344421 & .0344407 & -3.90 & 0.000 & -.2020124 & -.0668719 \\
\hline SexHead | & .000482 & .0725383 & 0.01 & 0.995 & -.141 & .1427971 \\
\hline OwnLand | & .0753056 & .0712039 & 1.06 & 0.290 & -.0643917 & .2150028 \\
\hline DistMark | & . 0033918 & .0023703 & 1.43 & 0.153 & -.0012586 & . 0080422 \\
\hline DistPrimS | & .003505 & .0037922 & 0.92 & 0.356 & -.0039351 & .0109451 \\
\hline DistHeal | & -.0061137 & .0016166 & -3.78 & 0.000 & -.0092854 & -.002942 \\
\hline DistTrans | & -.0026459 & .0005667 & -4.67 & 0.000 & -.0037578 & -.0015341 \\
\hline OwnTool | & .0795843 & .0407641 & 1.95 & 0.051 & -.000392 & .1595605 \\
\hline OwnRadio | & 3011017 & .0350128 & 8.60 & 0.000 & .2324089 & .3697945 \\
\hline OwnHous1 | & .0418804 & .0654668 & 0.64 & 0.522 & -.0865609 & .1703217 \\
\hline & & 25 & & 0.000 & 71 & 8.181171 \\
\hline
\end{tabular}

Following the above estimations, predicted base values of the dependent variable were calculated using the above regression estimates and model equation 1 . The national poverty line, which is estimated based on the same data set is directly 
applied. Using the predicted values and the model questions in 2,3 and 4 , the following poverty estimates were obtained for the base year.

\begin{tabular}{|c|c|c|c|c|c|}
\hline Variable & Obs & Mean & Std. Err & \multicolumn{2}{|c|}{ hf. Interval] } \\
\hline $\begin{array}{l}\text { P0j | } \\
\text { P1i | }\end{array}$ & $\begin{array}{l}7094 \\
7094\end{array}$ & $\begin{array}{l}.4023766 \\
.1124352\end{array}$ & $\begin{array}{l}0019878 \\
.0007994\end{array}$ & $\begin{array}{c}.39848 \\
.1108681\end{array}$ & $\begin{array}{r}4062733 \\
.1140022\end{array}$ \\
\hline P2j I & 7094 & .2489921 & .0004134 & .2481818 & 2498025 \\
\hline Popul & 7503 & 6266.799 & 52.63027 & 6163.629 & 6369.969 \\
\hline
\end{tabular}

Hence, the base simulation has provided a poverty incidence of 40.2 percent in rural areas with 11.2 and 24.9 poverty gap and severity respectively.

\section{Simulation of poverty to year 2000}

\section{Assumption 1.}

Given the above actual and base simulation poverty measures for the year 1995/96, attempt is made here to estimate poverty levels in five-year after the base year. The percentage change in percapita value added of agricultural production is assumed to reflect the same percentage change in consumption per capita (adult). During this period percapita agricultural production has declined, on average, by -3.4 percent annually. In other words, percapita agricultural value added has declined by about 15.9 percent during the five-year period. Hence, per adult deflated consumption expenditure is also assumed to have declined by the same level. If we assume, income distribution has remained the same during this period, the application of the same poverty line in real terms, has provided poverty estimates for the year 2000/01 as follows:

\begin{tabular}{|c|c|c|c|c|c|}
\hline Variable | & Obs & Mean & Std. Err. & \multicolumn{2}{|c|}{ [95\% Conf. Interval] } \\
\hline & & $. \overline{6} \overline{6} 4 \overline{8} \overline{7} 2-$ & $.0 \overline{1} \overline{1} \overline{0} 2 \overline{4}$ & $6 \overline{3} 2 \overline{75} \overline{8}$ & $\overline{6402 \overline{1} \overline{6}}$ \\
\hline $\mathrm{P} 1 \mathrm{j0} 0$ & 7094 & .2205062 & 0010994 & .2183511 & 2226613 \\
\hline$P 2 j 0 \mid$ & 7094 & .2754168 & 0001746 & .2750745 & .2757591 \\
\hline Popul | & 7503 & 6266.799 & 52.63027 & 6163.629 & 6369.969 \\
\hline
\end{tabular}

Note that, annual inflation based on CPI has been on average 2.64 during the fiveyear period, which means the poverty line has to be increased by 13.9 percent. The poverty line in 2000 becomes, therefore, 1224 birr.

Poverty level in rural areas in the country by 2000 should have increased, therefore, to 63.6 percent with increased poverty gap at 22.0 and severity at 27.5 . Such rapid increase in poverty level goes very with the general perception of the public as expressed during the PRSP consultation. A similar level of poverty was estimated 
based on survey data that was collected in selected rural areas in the country by the Economics Department of the Addis Ababa University.

Hence, while consumption expenditure and, therefore, agricultural value added per capita declined by 16 percent, poverty incidence has increased by 58 percent, implying agricultural growth elasticity of poverty -3.62 , which is very high.

\section{Assumption 2}

Given that the majority of farmers are subsistence farmers who are not affected by market price as such, if we assume, inflation level as zero, then the poverty estimates will be:

\begin{tabular}{|c|c|c|c|c|c|}
\hline Variable & Obs & $-\overline{\text { Mean }}=\overline{3} \overline{3} \overline{2} \overline{1} \overline{1} \overline{2}$ & $\begin{array}{l}\text { Std. Err. } \\
\overline{.00} 0 \overline{1} \overline{1} \overline{1}\end{array}$ & 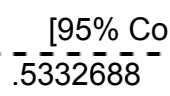 & ff. Interval] \\
\hline P1j1 | & 7094 & .0635812 & .0011546 & .0613178 & . 0658446 \\
\hline P2j1 | & 7094 & .2754168 & .0001746 & .2750745 & 2757591 \\
\hline Popul | & 7503 & 6266.799 & 52.63027 & 6163.629 & 6369.969 \\
\hline
\end{tabular}

Still, poverty incidence has increased by about 34 percent, providing agricultural growth elasticity of poverty to be -2.12 .

\section{Assumption 3}

If we assume for the moment that what is to be applied as a trend indicator beginning from 1995/96 is the long-term trend, which is a decline in agricultural value added per capita by 1.61 percent, then poverty estimates by 1999/00, 2004/05, 2009/10 and 2014/15 will be as follows:

\section{Assuming further that inflation will remain constant}

Consumption per adult expenditure in rural areas will decline by about 7.8 percent in the first five year period and by 15 percent in 2005, by 21.6 percent in 2010 and by 27.7 percent in 2015 . Hence,

Poverty still has increased (by 15.7 percent) with this relatively better long-term trend in agricultural value added percapita growth. In this case, agricultural growth poverty elasticity becomes -0.98 , or almost equal percentage change in opposite direction. So, it is likely that at least or as a minimum a one percentage increase in agricultural per capita value added will result into a one percent decline in poverty level.

\section{In the year 2000}

\begin{tabular}{|c|c|c|c|c|c|}
\hline Var & Obs & & & \multicolumn{2}{|c|}{ [95\% Conf. Interval] } \\
\hline & & & &.$\overline{4} 6 \overline{1072}$ & $46 \overline{90172}$ \\
\hline P1j00Lt & 7094 & .1374843 & .0008906 & .1357384 & .1392302 \\
\hline P2j00Lt | & 7094 & .2594333 & .0003295 & .2587874 & .2600793 \\
\hline Popul | & 7503 & 6266.799 & 52.63027 & 6163.629 & 6369.969 \\
\hline
\end{tabular}




\section{Poverty by 2015}

Based on long-term actual trend in agricultural percapita value added, a simulation was made to estimate poverty levels by the year 2015. Inflation level is assumed to remain constant concerning the poverty line, which is taken as fixed and that there will be no change in income distribution. Based on this assumption, poverty measures simulated for the year 2015 are as follows:

\begin{tabular}{|c|c|c|c|c|c|}
\hline Variable | & Obs & Mean & Std. Err. & \multicolumn{2}{|c|}{ [95\% Conf. Interval] } \\
\hline & & & & & וכנס \\
\hline P1j15Lt| & 7094 & .2294721 & .0011149 & .2272866 & .2316575 \\
\hline P2j15Lt | & 7094 & .2763801 & .0001709 & .2760451 & .2767152 \\
\hline Popul I & 7503 & 6266.799 & 52.63027 & 6163.629 & 6369.969 \\
\hline
\end{tabular}

Indeed, about two-third of the rural population will be in absolute poverty by 2015 if past performance of the sector continues unchanged, i.e., an increase in poverty incidence by 62 percent. During the same period, based on long term trend of agricultural percapita decline by 1.6 percent, the overall reduction in per adult consumption expenditure during the fifteen year period is 27.7 percent. In the face of such mounting challenge, the realization of the millennium goals in Ethiopia is unlikely.

If we assume the last five trends continue as the best scenario

Agriculture value added per capita was growing at .04 percent (i.e., the agriculture sector growing by 3.04 percent $\&$ assuming population was growing by 3 percent). So, by 2015 , consumption expenditure per adult could be assumed to increase by 8.3 percent. This will provide the following poverty estimates:

Hence, in this case, it was able to reduce poverty level by 2015 by 15 percent. Consumption expenditure per adult has increased by 8.3 percent during the same period. So, agricultural elasticity of poverty growth would be -1.8 .

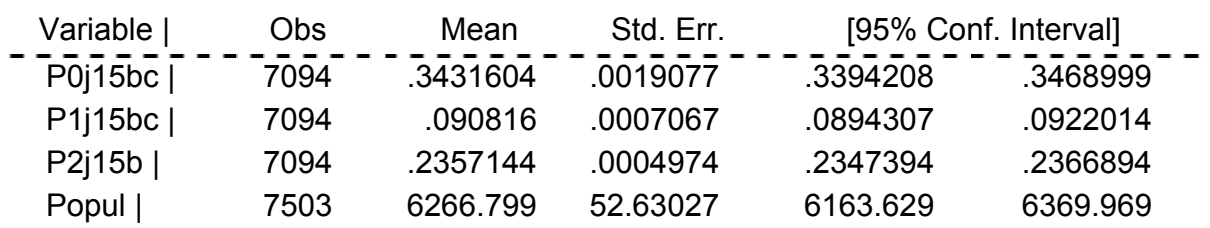

The results of the regression analyses are summarized in the table below. Given past trends, poverty level in the country will increase tremendously in the coming period. If the declining trend in agricultural percapita growth is not reversed, Ethiopia faces deterioration of welfare situation and about two-third of the population will be in 
absolute poverty by 2015. However, if agricultural productivity increases and registers a positive percapita growth poverty levels could actually be reduced as the growth elasticities of poverty calculated in different scenarios have clearly shown very high return in terms of poverty reduction from a growth in farm productivity.

Table 4.1: Summary of different scenario simulations

\begin{tabular}{lcccc}
\hline & $\begin{array}{c}\text { Annual growth } \\
\text { in consumption }\end{array}$ & $\begin{array}{c}\text { Change in } \\
\text { Po by 2000 }\end{array}$ & \multicolumn{2}{c}{ Elasticity } \\
\cline { 4 - 5 } & -3.4 & $58 \%$ & -3.62 & 2000 \\
\hline Last 5 yrs actual trend & -3.4 & $34 \%$ & -2.12 & \\
Last 5 yrs actual trend \& no inflation & -1.61 & $16 \%$ & & -0.98 \\
Long term trend and no inflation & 0.4 & $-15 \%$ & & -1.8 \\
Same five-year actual trend & & & \\
\hline
\end{tabular}

The functioning of any individual farm system is strongly influenced by the external and rural environment, including policies and institutions, markets and information linkages. Not only are farms closely linked to the off-farm economy through commodity and labour markets, but the rural and urban economies are also strongly interdependent. Although in Ethiopia the significance of off-farm activity is not as high as commonly observed in other countries, small farm households still depend very much on this source. Farm women and men are also linked to rural communities and social networks, and this social capital influences the management of farms.

\section{Conclusions and policy recommendations}

The most important basic deprivation in Ethiopia is lack of access to adequate food. The importance of the agriculture sector is, therefore, starkly clear. In Ethiopia, food insecurity is manifested in its extreme form of hunger and famine. Some 5 million people are estimated to be in need of relief food annually due to the nation's inability to produce and/or acquire its total food requirement as well as the inability of the vulnerable populations to access the food even if it were available on the market.

The problems of food insecurity in Ethiopia should be seen from their chronic and structural natures. Rapid population growth, declining land holding size, soil erosion, deforestation, poor technical know-how and rainfall dependent agriculture are some of the root causes of food insecurity in Ethiopia. Productivity in the agriculture sector is low and reliant primarily on rain fed production. The level of harnessing of available water supplies is also estimated to be a mere $11 \%$ of the total potential. 
However, limited land of 'acceptable' quality remains available for future agricultural use. Much of the limited available land is probably suited to a narrow range of crops. Hence, further expansion is simply not a promising option. Areas for potential expansion also suffer from one or more soil or terrain constraints and usually are inhospitable from health point of view. Hence, there is a critical need for improving the performance of the agriculture sector by raising its productivity levels.

The long term trend analysis made in chapter 2 has shown that overtime the significance of the sector in the overall economy has been declining as a result of a general decline in growth of percapita value added of the sector. Its share in GDP and overall employment has declined significantly during the past four decades. Yet, it still remains to be the dominant sector.

The trend in the overall GDP was highly determined by the trend in the performance of the agriculture sector. The fact that GDP percapita has shown no improvement over such long period is mainly the result of poor performance in the agriculture sector. The welfare of the people has also shown a declining trend in line with weakening of the agriculture sector.

The different simulation estimates made under different scenarios have also clearly indicated that unless the declining trend of the sector achievement is arrested and reversed, poverty situation in the country will rapidly aggravate as a result of which, say, by 2015 , close to about two-third of the population will be in absolute poverty. At the same time, it was shown that with little improvement in agricultural productivity, the trend in worsening poverty could be reversed and poverty actually reduced substantially by 2015 . This is especially called for considering the fact that the industrial base of the economy has shown little improvement negatively affected probably by the weak agricultural sector among other factors. The service sector is gaining increasing significance and it has surpassed the contribution of agriculture to GDP in the last three years. This is a worrisome trend given that it cannot be sustainable in the long term.

Some of the key conditions that affect the size of the contribution of agricultural growth to poverty reduction identified in this study include the following: A) Access to market; because the rural sector is largely non-monitized an increase in level of agricultural production may not effectively translate into an increase in rural households' income. B) Absence of infrastructure such as roads, communication and transport, i.e., barriers to connection with outside markets. C) Scattered nature of settlement in rural areas acts as a barrier of benefit accumulation or acceleration. Scattered settlement also makes it difficult and costly to provide access to education, 
health and infrastructure services. D) Inadequacy of urban demand which is characterized by small population size and underdeveloped industrial sector.

The overall facts detect the need for addressing the constraints faced by the agriculture sector as top development priority. The long-term declining trend in agricultural value added percapita needs to be addressed at policy level. The decline in the share of agriculture should not come as a result of a decline in the growth volume of agricultural output. Even under structural transformation, it is the degree of relative growth between agriculture and the remaining sectors that vary rather than absolute decline in its performance. Hence, ways should be explored to create dynamism in the sector. In particular, the sector should not be seen as an island on its own but as a driving force of growth in other sectors taking into consideration, therefore, sectoral interdependence and rural-urban linkages.

Ethiopia needs to feed itself on priority basis before any other form of development is envisioned. It simply will not be decent and practical to talk of other dimensions of development without first resolving the food insecurity issue. The current trend in level of hunger is largely determined by the onset of adequate and timely rainfall. Given that the frequency and severity of drought seem to have increased over time, fundamental restructuring of the sector is needed. In particular, giving the growing population pressure and scarcity of land and growing landlessness, the land tenure system needs to be revisited and revised to create conducive environment for rapid development of the sector.

Given the low level of urbanization and consequent inadequacy of domestic demand, the competitiveness of the agriculture sector and its orientation to production for export is crucially demanded. The IFIs have pushed Ethiopia to rapidly remove price controls and subsidies to farmers. Transportation and freight prices were deregulated serving to boost food prices in remote areas affected by drought. In turn, markets for farm inputs including fertilizer and improved seeds were handed to private traders. Given the results obtained in this study which indicated farmers suffering from fertilizer use and slumping prices of agricultural produce, some form of price control and subsidy to farmers need to be considered. The issue of scattered settlement in rural areas where most rural communities are isolated from the rest of the society is identified as key barrier to rural transformation. Hence, carefully planned voluntary villagization and settlement programs need to be implemented. 


\section{References}

Alain de Janvry, Elisabeth Sadoulet, et al. (2002). Geography of poverty, territorial growth, and rural development.

Ali, Ali Abdel Gadir (1998). Dealing with poverty and income distribution issues in developing countries -- Cross regional experiences, API, Kuwait.

Alderman, H., Cord, L., et al. (2001). Rural poverty, Source Book, World Bank.

Befekadu Degefe, Berhanu Nega and Getahun Tafesse (2002). Second annual report on the Ethiopian economy, EEA/ EEPRI, Vol. II 2000/2001, Addis Ababa.

Colin Thirtle and Lindle Beyers, et al. (2002). The impact of changes in agricultural productivity on the incidence of poverty in developing countries, DFID report No.7946

Colin Thirtle, Lin Lin and Jenifer Piesse (2002). The impact of research led agricultural productivity growth on poverty reduction in Africa, Asia and Latin America. Research paper 016 . The management center research papers, University of London

ECA (1999). the challenges of poverty reduction and sustainability, Addis Ababa.

Eshetu Chole (1995). The dismal economy, Addis Ababa.

GOE, IPRSP (2000). MoFED

Inderjit Singh, Lyn Squire, and John Strauss (1986). Modeling agricultural household models: Why and how?

Inderjit Singh, Lyn Squire, and John Strauss (1986). An overview of agricultural household models.

Martin Ravallion, Gaurav Datt (2001). Why has economic growth been more pro-poor in some states of India than others?, World Bank.

(1996). How important to India's poor is the sectoral composition of economic growth?, IBRD, The World Bank.

Nanak Kakwani (1993). Poverty and economic growth with application to Cote d'ivoire, review of income and wealth series 39.

Pranab Bardhan and Christopher Udry (1999). Development microeconomics. Oxford University Press, Oxford.

WMU, MEDaC (1999). Poverty situation in Ethiopia, Addis Ababa.

Krishnan Ramadas, Bernadette Ryan and Quentin Wondon (2002). SimSIP Goals: Assessing the realism of development targets. 